\title{
Corporate Ethics And Ethical Behaviour: The Significant Function Of Top Management Role Modelling
}

Pablo Ruiz-Palomino, Ph.D., University of Castilla-La Mancha, Spain Ricardo Martínez-Cañas, Ph.D., University of Castilla-La Mancha, Spain

\begin{abstract}
Despite growing professional and academic interest in business ethics, moral lapses continue in the business sector, which suggests a need to rethink the efficiency of existing ethical strategies. That is, top management's efforts to promote ethical behaviour among employees tend to focus on the implementation of explicit formal mechanisms, whereas in practice, more informal elements that communicate the true attitude toward ethics may be more useful and necessary. Thus top managers must work actively to make their personal ethics evident to influence the ethical behaviours of employees. Without a perception of ethics at the top, formal mechanisms likely fail to result in a more ethical workforce. This study therefore empirically analyses top managers' role modelling behaviour along with the efficacy of their sanctioning dimension to promote ethical behaviour. Top management role modelling has a positively impact on employees' ethics; sanctioning behaviour does not. These findings have critical practical implications, as well as promise for further research.
\end{abstract}

Keywords: Top Management; Role Modelling; Sanctioning Behaviour; Ethical Behavioural Intentions

\section{INTRODUCTION}

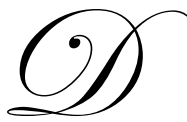

espite great attention to and efforts by academics, professionals and society to avoid immorality in the business sector, moral scandals have not ceased. Ethical failures in the business sector (e.g. bribery, falsifying reports, stealing, deceptive advertising) appear in media reports, many of which point to the involvement of high levels of management in the immoral acts. The study and understanding of ethical behaviours in organizations thus must advance if we are to minimise further ethical failures in business.

Considerable efforts have aimed at implementing ethical standards in international business spheres (Weaver, Treviño \& Cochran, 1999; IBE, 2008), yet most of the companies that gained reputations as "rotten apples" had in place organisational procedures, mechanisms or systems to promote ethics (Sims \& Brinkman, 2003). Those mechanisms reportedly are useful for improving the level of morals in organisations, according to vast literature. But if the implementation of these mechanisms does not involve deeds and the sincere commitment of organisational leaders with formal authority, their effectiveness may be mitigated. For this study, we assess the role of top management in influencing the ethical behaviour of employees. Specifically, by examining the impact of sanctioning and role modelling by top management, we reveal that more emphasis should be placed on role modelling if the firm hopes to encourage ethical behaviour among its workforce.

We present a theoretical background to lead into our hypotheses, then outline the method we used to test those hypotheses. We discuss the relevant findings before offering some possible limitations of our study, practical contributions and implications for further research. 


\section{THEORETICAL BACKGROUND AND HYPOTHESES}

\section{Top Management Sanctioning Behaviour}

Traditionally, the tactics used by top management to reduce immorality in their companies have involved the implementation of organisational and formal mechanisms (Ford \& Richardson, 1994; O'Fallon \& Butterfield, 2005), such as codes of conduct, training initiatives, ethical officers, ethical auditing and reporting or ethics ties to the performance system. According to previous research, these tactics also are some of the most commonly used instruments in European companies, especially in the Spanish business context (Guillen, Melé \& Murphy, 2002). A system of rewards and punishments based on ethical actions has been cited as a necessary element for achieving a reputation for ethical leadership (Treviño, Hartman \& Brown, 2000; Treviño \& Nelson, 2004). Such system plays an important role in social influence processes; as Bandura (1977) argues, a person behaves in accordance with the negative or positive consequences that attach to his or her behaviours, such as avoiding behaviours linked to negative consequences and acting in ways that lead to positive consequences. Therefore, sanctioning unethical behaviours should encourage ethics among employees. Furthermore, this mechanism fulfils an informative, motivating and reinforcing function in the business organization (Bandura, 1977). Top management efforts to discipline unethical behaviour should offer an effective strategy to encourage ethical behaviour, which we express formally as follows:

Hypothesis 1: Top management sanctioning behaviour toward immorality relates positively to employees' ethical behaviour.

\section{Top Management Role Modelling}

Even if formal mechanisms are valid and effective in improving the ethical quality of a business organization (Ford \& Richardson, 1994; O'Fallon \& Butterfield, 2005), if ethics are absent at the top management level, an ethical organizational climate might not be easily achievable (cf. Schroeder, 2002; Weaver, Treviño \& Agle, 2005). Top management's behaviour thus affects the level of ethics among employees. In role set theory (Merton, 1957), a referent's level of formal authority determines his or her influence on an employee's behaviour and attitudes. Because top managers have great formal authority, their behaviour, values and decisions should exert strong influences over employees' ethical behaviours. It may be difficult for employees to perceive the personal behaviours of top managers directly, but the top management level likely develops (even if unconsciously) a reputation for ethical or unethical, hypocritical or ethically neutral leadership (Treviño \& Nelson, 2004). For example, rumours about decisions, strategies and behaviours (both in private and corporate settings) by top managers likely circulate throughout the organization and contribute to their ethical image. Therefore, top management needs to develop a reputation for ethical leadership if ethical behaviour among employees is desired to be encouraged. Ethics must start at the top; even if the firm implements various formal, ethics-related mechanisms, they cannot truly influence employees' ethics if those mechanisms do not match the ethical image at the top (cf. Schroeder, 2002), in which case top management instead could be perceived as hypocritical (Treviño et al., 2000; Treviño \& Nelson, 2004). Thus top management ethicality is one of the most important determinants of company ethics (Zabid \& Alsagoff, 1993; Vitell, Dickerson \& Festervand, 2000), and making such ethics evident to all organizational members should strongly affect the ethical behaviour of employees. In turn, we propose:

Hypothesis 2: Top management ethical role modelling relates positively to employees' ethical behaviours.

\section{METHODOLOGY}

\section{Sample and Procedure}

Surveys were distributed to 4164 employees working in large branches or offices of banks spread across five Spanish provinces. We received a total of 436 usable surveys, for a response rate of 10.5\%. To minimize apprehension and decrease social desirability bias, we informed respondents, in the cover letter, that there were no "right" or "wrong" answers. In addition, the letter guaranteed total anonymity. Although respondents were relatively young ( $49 \%$ younger than 40 years), the sample featured high seniority $(60 \%$ had worked more than ten years for 
the same company) and high education levels (more than $65 \%$ had college degrees). In addition, though $26 \%$ of the sample did not respond to the gender issue, $46 \%$ of the sample identified themselves as men and $28 \%$ as women.

\section{Measures}

We measured top management sanctioning behaviour with one item from the sanctioning dimension of the Corporate Ethical Values scale (Hunt, Wood \& Chonko, 1989). With a five-point response format $(1=$ strongly disagree, $5=$ strongly agree), the item asked about the extent to which employees perceived that top management in their company disciplined people who committed unethical acts.

One item, adapted from Treviño, Butterfield and McCabe's (1998) scale, measured top management role modelling in terms of ethics. The item, "The Top Manager in my organization is a model of ethical behaviour," used a five-point response format $(1=$ strongly disagree, $5=$ strongly agree $)$.

Finally, similar to other studies of business ethics (Fritzsche \& Oz, 2007), we measured ethical behavioural intention (EBI) as a proxy for actual behaviour (Azjen \& Fishbein, 1980). Four vignettes adapted from prior studies (Peterson, 2004) described a hypothetical employee who had committed a questionable moral act (misuse, lying, theft or dishonest defamation). In a five-point response format $(1=$ strongly disagree, $5=$ strongly agree $)$, respondents indicated their level of agreement with the actions taken in each vignette, in response to the item, "I would be likely to act similarly in that situation." The responses were reverse-scored and averaged, so higher values represented a stronger intention to behave ethically.

\section{Data Analysis}

We used SPSS (v.19.0) statistical software to generate descriptive statistics and the correlation analysis of the data. The correlation analysis and an independent-samples t-test serve to test our hypotheses. As we show in Table I, the reliability of the dependent measure is acceptable. The Cronbach's alpha coefficient for the dependent variable is slightly lower than the minimum level of 0.7 recommended by Nunnally (1978) for basic research, but additional statistical analyses (i.e., single factor for four items, acceptable item correlation levels with respect to the scale's corrected total) reveal the appropriateness of the measure. In addition, according to Hair, Black, Babin, Anderson and Tatham (2006), levels of 0.60 and higher are acceptable, especially for exploratory scales.

\section{RESULTS}

\section{Hypothesis Testing}

In our descriptive analysis of the data, we observed high levels of ethicality among the banking respondents $($ Mean $=3.68 ; \mathrm{SD}=0.72)$. However, the respondents' perceptions reveal that on average, top management does not seem very interested in ethics, at least in terms of modelling behaviour (Mean $=2.66$; $\mathrm{SD}=1.00$ ) or sanctioning immorality $($ Mean $=2.71 ; \mathrm{SD}=1.05)$.

Table I

Means, standard deviations and correlation matrix

\begin{tabular}{|c|c|c|c|c|c|}
\hline & Mean & SD & 1 & 2 & 3 \\
\hline 1. Ethical behavioural intention (EBI) & 3.68 & 0.72 & 0.62 & & \\
\hline 2. Top management sanctioning behaviour & 2.66 & 1.00 & $0.01^{\text {n.s. }}$ & n.a. & \\
\hline 3. Top management role modelling & 2.71 & 1.05 & $0.146 * *$ & $0.296 * *$ & n.a. \\
\hline
\end{tabular}

Notes: Diagonal cells in bold indicate Cronbach's alpha values. Off-diagonal elements are correlations between variables.

n.a.: not applicable. ** Significant at the .01 level (one-tailed).

We performed a correlation analysis to test the strength and direction of the linear relationship between the target variables: top management role modelling, top management sanctioning behaviours and EBI. In Table I, the results indicate some preliminary support for Hypothesis 2: The real association between role modelling and EBI (r $=0.146$ ) is significant at $p<.01$ in the predicted direction. However, we did not find support for Hypothesis 1 , because the association between sanctioning and EBI was not significant $(r=0.01)$. 
To check and confirm these results, we conducted two independent-sample t-tests. The first independent sample t-test revealed if the means of two different populations (who perceived top management sanctioning behaviour as either high or low) differ statistically from each other in terms of the employee's EBI. As we show in Table II, and in line with our preceding results, we must reject Hypothesis 1, because the test is insignificant at $t$ $(426)=0.224$. Employees who perceive top management sanctioning behaviour as high $(M=3.79, S D=0.66, \mathrm{n}=$ 249) on average do not behave more ethically than those who perceive that top management sanctioning behaviour is low $(M=3.77, S D=0.67, \mathrm{n}=179)$.

The second t-test enabled us to contrast respondents with different perceptions of top management role modelling and revealed a significant result at $t(429)=2.456$ (see Table II). Those who perceived high top management ethical role modelling $(M=3.85, S D=0.65, \mathrm{n}=257)$ behaved more ethically than those who perceived low top management ethical role modelling $(M=3.69, S D=0.68, \mathrm{n}=174)$. In addition, with $95 \%$ confidence, we can assert there is always a mean difference between the two conditions related to Hypothesis 2 , ranging from 0.03 to 0.28 , which indicates significant differences (in the predicted direction) in the mean level of EBI among employees who have varying perceptions of top management role modelling.

Table II

Top management behaviours and EBI: Independent sample t-tests

\begin{tabular}{|c|c|c|c|c|c|c|c|}
\hline & $\mathbf{M}$ & SD & $\mathbf{M}$ & SD & t-Statistic & $p$-Value & 95\% Confidence Interval \\
\hline $\begin{array}{l}\text { Perceptions of } \\
\text { sanctioning } \\
\text { behaviour }\end{array}$ & \multicolumn{2}{|c|}{ High $(\mathrm{n}=249)$} & \multicolumn{2}{|c|}{ Low $(\mathrm{n}=179)$} & & & \\
\hline Ethical intention & 3.79 & 0.66 & 3.77 & 0.67 & 0.224 & $0.823^{\text {n.s. }}$ & $-0.11-0.14$ \\
\hline $\begin{array}{l}\text { Perceptions of role } \\
\text { modelling }\end{array}$ & \multicolumn{2}{|c|}{ High $(n=257)$} & \multicolumn{2}{|c|}{ Low $(\mathrm{n}=174)$} & & & \\
\hline Ethical intention & 3.85 & 0.65 & 3.69 & 0.68 & 2.456 & $0.007 * *$ & $0.03-0.28$ \\
\hline
\end{tabular}

Notes: $n . s .=$ not significant. $* *$ Significant at 0.01 level (one-tailed).

In summary, both the correlation analysis and the independent t-tests offer support for Hypothesis 2 but not for Hypothesis 1. Sanctioning behaviour does not appear to affect employees' ethical behaviour significantly, whereas role modelling has important and positive effects on employees' ethics, at a significance level of $p<0.01$.

\section{DISCUSSION}

The purpose of this study has been to explore how top management influences employees' ethical behaviour through its sanctioning and role modelling. To better understand the mechanisms leading to ethical or unethical behaviour among employees, we have examined the impact of top management role modelling and sanctioning behaviours, but we find mixed results. Employees' ethical behaviours are positively affected by top management role modelling, but they remain unaffected by sanctioning behaviour. The latter result is unexpected, according to prior literature (Ford \& Richardson, 1994, O'Fallon \& Butterfield, 2005), though ours is not the only study to find an insignificant association between sanctioning mechanisms and ethical behaviours of employees (Beams, Brown \& Killough, 2003). The isolated use of negative reinforcement, such as sanctioning, could appear threatening to employees, which might minimise its influence and its effectiveness for decreasing unethical behaviours among employees.

The findings from this study also reveal a key implication for business practice with regard to increasing the level of ethics. The most important strategy for enhancing ethics in business organizations entails emphasising the exemplary ethical conduct of top management. Ethical obligations usually are understood as mutual or reciprocal (Schroeder, 2002), so if ethics are to invade the organisation, they must start at the top. This study elucidates the important function of top management role modelling as a strong determinant of employees' ethical thinking and behaviour, more important even than formal organisational mechanisms, such as those related to sanctioning immoral behaviours. 
This study also contains several limitations. First, our findings are limited to the particular context of banking in Spain. Although similar results may emerge in other socio-cultural contexts, the external validity and generalisation of our results beyond our study population is questionable, especially because cultural characteristics could affect our findings. Second, we ignore individual characteristics, even though prior literature (Treviño, 1986; Greenberg, 2002) suggests they may interact with the top management variables we have analysed. For example, women tend to depend more on external authority and comply with regulations, whereas men display more independent thinking and action (Beu \& Buckley, 2001). Therefore, as some previous studies note (Leming, 1980), personal characteristics such as gender could make employees less or more open to the influence of sanction threats, and these traits could have influenced our results as well.

Finally, we note the importance of analysing such interactive individual-organizational effects, as well as various other interactions, such as those between the organizational factors studied here and many others of an organizational type. The analysis of interactions between organizational factors would allow us to contrast, for example, the role of congruence between ethics related organizational mechanisms to impact significantly on the employees' ethical behaviour. In the special case of top management sanctioning, such congruence could be especially important, because without it, top management appears hypocritical and likely has little or no influence on employees' ethicality (Treviño \& Nelson, 2004). Further research also could improve on our independent variable measures by adding more items. For example, measures of top management sanctioning might incorporate a positive reinforcement dimension, such as rewarding.

\section{AUTHOR INFORMATION}

Pablo Ruiz-Palomino, Assistant Professor of Business Administration at University of Castilla-La Mancha (Spain). He received his Ph.D. in Business Administration and recently was awarded the 2009 MSD-FORETICA prize in business ethics research. His current research interests include business ethics, leadership and social capital. E-mail: Pablo.Ruiz@uclm.es.

Ricardo Martinez-Cañas, Assistant Professor of Business Administration at University of Castilla-La Mancha (Spain), where he also received his Ph.D. in Business Administration. His current research interests focus on business ethics, social capital and strategy. E-mail: Ricardo.Martinez@uclm.es.

\section{REFERENCES}

1. Ajzen, I. \& Fishbein, M. (1980). Understanding Attitudes and Predicting Social Behaviour. Englewood Cliffs, NJ: Prentice Hall.

2. Armstrong, J.S. \& Overton, T.S. (1977). Estimating Non-Response Bias in Mail Surveys. Journal of Marketing Research, 14 (3), 396-403.

3. $\quad$ Bandura, A.: 1977, Social Learning Theory (Prentice Hall Inc, Englewood Cliffs, NJ).

4. Beams, J.D., Brown, R.M. \& Killough, L.N. (2003). An Experiment Testing the Determinants of Non Compliance with Insider Trading Laws. Journal of Business Ethics, 45 (4), 309-323.

5. Beu, D. \& Buckley, M.R. (2001). The Hypothesized Relationship Between Accountability and Ethical Behavior. Journal of Business Ethics, 34, 57-73.

6. Ford, R.C. \& Richardson W. D. (1994). Ethical Decision Making: A Review of the Empirical Literature. Journal of Business Ethics, 13, 205-221.

7. Fritzsche, D. \& Oz, E. (2007). Personal Values' Influence on the Ethical Dimension of Decision Making. Journal of Business Ethics, 75 (4), 335-343.

8. Guillén, M., D. Melé \& Murphy P. (2002). European vs. American Approaches to Institutionalisation of Business Ethics: The Spanish Case. Business Ethics: A European Review, 11 (2), 167-178.

9. Greenberg, J. (2002). Who Stole the Money, and When? Individual and Situational Determinants of Employee Theft. Organizational Behaviour and Human Decision Processes, 89 (1), 985-1003.

10. Hair, J.F. Jr., Black, W.C., Babin, B.J., Anderson, R.E., \& Tatham, R.L. (2006). Multivariate Data Analysis. (6 ${ }^{\text {th }}$ Ed.). New Jersey: Prentice Hall International.

11. Hunt, S.D., Wood, V.R. \& Chonko, L.B. (1989). Corporate Values and Organizational Commitment in Marketing. Journal of Marketing 53, 79-90. 
12. I.B.E. (Institute of Business Ethics) (2008). The 2008 National Survey: Employee Views of Ethics at Work. Available at: http://www.ibe.org.uk/publications/listofpublications.htm [Accessed on November 20, 2009].

13. Nunnally, J. (1978). Psychometric Theory, 2nd Edition, New York: McGraw-Hill.

14. Leming, J.S. (1980). Cheating Behavior, Subject Variables and Components of the Internal-External Scale under High and Low Risk Conditions. Journal of Educational Research, 74, 83-87.

15. Merton, R.K. (1957). The Role Set: Problems in Sociological Theory. British Journal of Sociology, 8 (2), 106-120.

16. O'Fallon, M.J. \& Butterfield, K.D. (2005). A Review of the Empirical Ethical Decision-Making Literature: 1996-2003. Journal of Business Ethics, 59 (4), 375-413.

17. Peterson, D.K. (2004). Perceived Leader Integrity and Ethical Intentions of Subordinates. Leadership \& Organization Development Journal, 25, 7-23.

18. Schroeder, D. (2002). Ethics from the Top: Top Management and Ethical Business. Business Ethics: A European Review, 11(3), 260-267.

19. Sims, R.R., \& Brinkman, J. (2003). Enron Ethics (or: Culture Matters More than Codes). Journal of Business Ethics, 45, 243-256.

20. Treviño, L.K. (1986). Ethical Decision Making in Organizations: A Person-Situation Interactionist Model, Academy of Management Review 11 (3), 601-617.

21. Treviño, L.K., Butterfield K.D., \& McCabe D.L. (1998). The Ethical Context in Organizations: Influences on Employee Attitudes and Behaviours. Business Ethics Quarterly, 8 (3): 447-476

22. Treviño, L K, Hartman L.P., \& Brown, M. (2000). Moral Person and Moral Manager: How Executives Develop a Reputation for Ethical Leadership. California Management Review, 42 (4), 128-142.

23. Treviño, L.K. \& Nelson, K.A. (2004). Managing Business Ethics: Straight Talk about How to Do It Right. New York: John Wiley \& Sons.

24. Vitell, S.J., Dickerson E.B., \& Festervand T.A. (2000). Ethical Problems, Conflicts and Beliefs of Small Business Professionals. Journal of Business Ethics, 28 (1), 15-24.

25. Weaver GR, Treviño LK, \& Cochran P.L. (1999). Corporate Ethics Practices in the Mid-1990's: An Empirical Study of the Fortune 1000. Journal of Business Ethics, 18 (3), 283-294.

26. Weaver G.R, Treviño LK, \& Agle B. (2005). Somebody I Look up to: Ethical Role Models in Organizations. Organizational Dynamics, 34, 313-330.

27. Zabid, A.R.M. \& Alsagoff, S.K. (1993). Perceived Ethical Values of Malaysian Managers. Journal of Business Ethics, 12, 331-337. 